\title{
Review
}

\section{Graft vascular function after transplantation of pancreatic islets}

\author{
L. Jansson, P.-O. Carlsson \\ Department of Medical Cell Biology, Uppsala University, Uppsala, Sweden
}

\begin{abstract}
Endogenous pancreatic islets have a dense glomerular-like angioarchitecture, which ensures an optimal delivery of oxygen and nutrients to the islet cells, provides signals from other cells in the body and disposes secreted hormones. Transplantation of isolated islets means that their vascular connection is interrupted. The islet grafts therefore depend upon endothelial cells and microvessels originating in the implantation organ for derivation of a new vascular system. A reestablishment of islet blood-flow occurs within 7-14 days after transplantation, mainly through vascular sprouting. The newly formed blood vessels acquire the morphological characteristics of those in endogenous islets. In intraportally transplanted islets to the liver, the islets become revascularized almost exclusively from tributaries to the hepatic artery. Exocrine contamination of the transplanted islets could hamper the revascularization process, whereas neither cryo-
\end{abstract}

preservation nor immunosuppressive drugs like cyclosporin, prednisolon and RS-61443 have any essential effects on the angiogenesis. Investigators have noticed improvements in islet graft survival and function by means of basic fibroblast growth factor (bFGF), acidic FGF and endothelial cell growth factor exposure of the grafts. The functional properties of transplanted islets are largely unknown, but evidence from experimental islet transplantation suggests that both the blood perfusion and the tissue oxygen tension of the grafted islets are chronically decreased, indicating an insufficient vascular system. In order to achieve optimal condition for survival and function of transplanted beta cells, it is important to ascertain whether impairments in vascular function are present also after clinical islet transplantations as well. [Diabetologia (2002) 45:749-763]

Keywords Revascularization, islet graft, angiogenesis, blood flow, oxygen tension.
The vasculature, and especially so the endothelium, of organs and tissues is uniquely adapted to the functional needs of the cells within that organ. In addition to

Received: 3 October 2001 / Revised: 31 January 2002

Published online: 15 May 2002

(C) Springer-Verlag 2002

Corresponding author: Dr. L. Jansson, Department of Medical Cell Biology, Biomedical Center, Uppsala University, Box 571, SE-751 23 Uppsala, Sweden, e-mail: Leif.Jansson@medcellbiol.uu.se

Abbreviations: FGF, Fibroblast growth factor; IAPP, islet amyloid polypeptide; ICAM-1, intercellular adhesion molecule 1; ICC, islet cell clusters; IFN-, $\alpha$ interferon- $\alpha$; NO, nitric oxide; NOS, nitric oxide synthase; VEGF, vascular endothelial growth factor mediating transport of nutrients, metabolites and hormones, the endothelium also affects blood perfusion through the production of endothelial vasoconstrictors and vasodilators [1]. Furthermore, endothelial expression of various integrins affects the recruitment of blood cells into the tissues, e.g. during insulitis [2, $3,4]$.

Transplantation of isolated islets leads to a total or partial loss of the original vasculature, which necessitates revascularization of the grafted islets to ensure adequate survival $[5,6,7,8]$. This means that grafted islets depend upon endothelial cells and microvessels originating in the implantation organ for derivation of their new vascular system, i.e. endothelium from a heterotopic site. Despite this, the transplantation of 
pancreatic islets in experimental animals has the potential to permanently cure diabetes mellitus [9]. Clinical islet transplantation, on the other hand has been largely disappointing, with only a handful of reported patients with long-term graft function [10]. Recently, application of the Edmonton protocol $[11,12]$ which, among other things, includes a markedly increased number of transplanted islets $(13,000$ islet equivalents (IEQ) for each $\mathrm{kg}$ body weight) has led to much higher success rates, with almost all patients achieving insulin independence. The need of this high number of transplanted islets might, at least partially, be due to a lack of proper engraftment and thereby a loss of many of the implanted endocrine cells [13]. In view of the shortage of islets for transplantations any possibility to achieve an optimal engraftment [6] is of utmost importance.

The purpose of this review is to outline in detail the changes in islet vasculature induced by transplantation, and in this context to discuss possible secondary functional alterations, and remedies for these.

\section{Normal islet vasculature}

Morphology of the vasculature of endogenous islets. The morphology of the pancreatic islets is highly complex with at least four different endocrine cell types organized around a sinusoidal network of fenestrated capillaries [14, 15]. Studies using scanning electron microscopy or vascular corrosion casts have demonstrated that the vasculature of the islets depends on the size of the islets. Smaller islets (diameter less than $100 \mu \mathrm{m}$ ) are included into a capillary network in common with exocrine cells. Larger islets, on the other hand, are supplied by 1-3 arterioles, branching from intralobular arteries [16]. Likewise, larger islets empty into venules, which form a basket-like network covering the surface of the islets [14].

In addition to the veins, some effluent blood vessels form into an insulo-acinar portal system, consisting of small vessels connecting the islet capillaries with capillaries in the exocrine parenchyma [17]. This portal system is believed to deliver high local concentrations of insulin to the exocrine acini, thereby providing a trophic stimulus for this tissue $[18,19]$. The extent of this system is species-dependent, and in rodents it seems as if large islets - that is those that are isolated for subsequent islet transplantations (see below) - mainly empty through venules directly into intralobular veins [14]. The conditions in human islets are less well known, with previous studies suggesting that the portal system is well developed [20, 21]. Even a third, ductal capillary system, connected in series to those in the endocrine and exocrine tissues could exist in mouse and rabbit pancreas [22, 23], though this concept has been challenged [24] (Fig. 1). Regarding the morphology and microcirculatory function of the

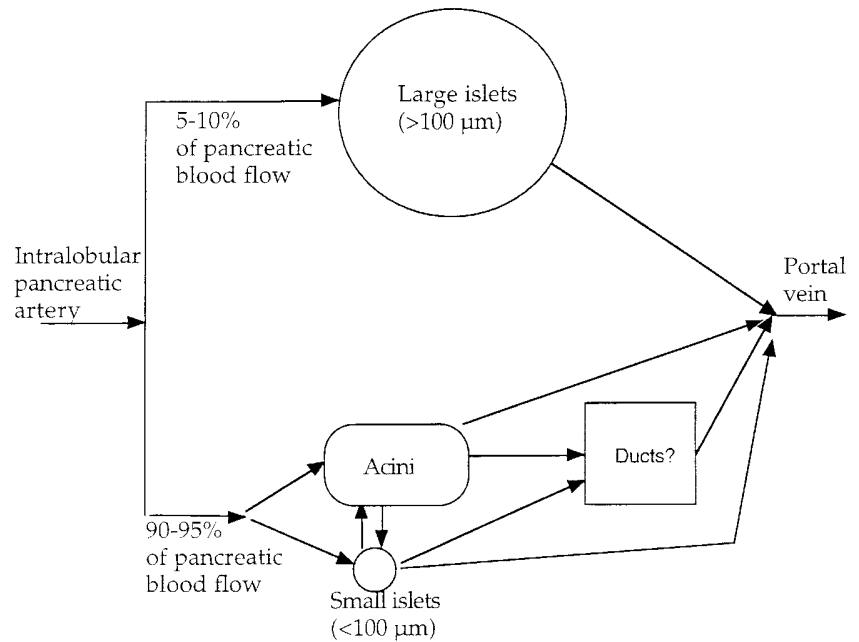

Fig. 1. Schematic representation of the vasculature of an endogenous pancreatic islet; modified from [30]

vasculature of human islets most data suggest that it is similar to that of rodent islets after experimental transplantation [25].

When the arterial blood vessels enter the islet they branch into a dense network of sinusoidal capillaries, with a morphological resemblance to renal glomeruli. These capillaries are of fundamental importance, not only for the delivery of oxygen and nutrients to the endocrine cells, but also to provide signals from other cells in the body, mediated through endothelial cell receptors [26], as well as for the disposal of the secreted hormones. Different opinions on the organisation of the endogenous islet vascular architecture have been presented [15]. According to one view, based on functional studies with anterograde and retrograde perfusions and administration of blocking antibodies, the distribution of the different cell types with regard to the blood capillaries is not random, but is organized so that the arterial blood first reaches the beta cells, then the alpha and delta cells, respectively [27]. In line with this view, the arterioles penetrate a discontinuity in the non-beta-cell mantle of the islets and branch from the central portions towards the periphery of the islets [28]. This means that the beta cells are not normally exposed to high concentrations of the other islet hormones.

On the contrary, experimental studies on vascular corrosion casts have been interpreted by some to demonstrate that the arterioles branch already in the periphery of the islets, thereby exposing the beta-cell rich islet core to high levels of somatostatin, glucagon and pancreatic polypeptide [17, 21, 29]. According to a third view, blood travels from the arterial pole of the islet to the venous pole regulated by external and internal gates without any preferential order of perfusion of the endocrine cells [30, 31]. For further references, see [15, 32].

Because the islet vasculature is disconnected by the isolation procedure before transplantation, the re- 
establishment of the vascular architecture after implantation would be of major importance to achieve an adequate graft function. It should also be kept in mind in this context, firstly, that islets isolated for the purpose of transplantation are usually large islets; secondly, they are either implanted as single islets (e.g. intraportally into the liver as in almost all human islet transplantation) or as aggregates of islets, such as under the renal capsule or into the spleen in experimental islet transplantation. The importance of this for revascularization will be further discussed below.

Blood perfusion of endogenous islets. A review of results on islet blood flow regulation, including studies performed with direct observations on the vasculature, has been published [31]. Quantitative determinations of endogenous pancreatic islet blood flow have become possible by modifications of a microsphere technique [31]. Such studies have shown that pancreatic islets have a blood perfusion of about $5-15 \%$ of that of the whole pancreas, despite comprising only $1 \%$ of the gland [32, 33, 34, 35]. Previous findings suggest that islet blood flow is autonomously regulated from the blood perfusion to the rest of the pancreas and is uniquely adapted to the needs of the endocrine cells [31].

To ensure an appropriate blood perfusion increase when the needs for secretion of insulin increase, islet blood flow is regulated both by nervous, endocrine and metabolic mechanisms [31]. The vagus nerve seems to be the most important entity when mediating this [36]. Glucose receptors connected to the vagus nerve, and responsible for this response, have been found in the brain, oral cavity and duodenum, whilst similar receptors in the liver mainly work through sympathetic nerves [36, 37, 38]. Because pancreatic islets are functionally denervated after transplantation $[39,40,41]$, this means that there is probably a change in the blood-flow regulation (see below). Transplanted whole pancreases, i.e. denervated glands, have been found to lack the islet blood-flow increase seen early after glucose administration [42]. Beginning about 10 min after induction of hyperglycaemia, the increased metabolic activity of the islets can also help to maintain a high islet-blood perfusion, mainly through adenosine [43]. Such mechanisms are likely to be more important for islet graft blood flow.

Islet blood flow is also influenced by gastrointestinal hormones, mainly incretins [31], and endothelial derived mediators, such as nitric oxide (NO), angiotensin II, endothelins and natriuretic peptides. It seems, for instance, as if an intact production of NO is necessary to maintain the high basal islet blood flow both in the endogenous [44, 45] and transplanted whole pancreas [46], and as if islet vasculature is more sensitive than exocrine blood vessels to the vasoconstrictor actions of endothelins and angiotensin II $[47,48]$.
We, and others, have in several studies noted marked disturbances in the islet vasculature, islet blood flow and capillary blood pressure during conditions with impaired glucose tolerance $[49,50,51,52$, $53,54]$. Similar findings have been made in animal models of Type I (insulin-dependent) diabetes mellitus [55]. Of particular interest in this context are the findings that islet endothelial cells in $B B$ rats, a Type I diabetes model, have a dysfunction of their constitutive nitric oxide synthase (cNOS) which correlates strongly with the probability for disease manifestation [56]. Islet blood flow is, as mentioned above, strongly influenced by NO, but it is not clear if the dysfunctional cNOS in these islets is associated with any changes in blood perfusion. Because capillary hyperperfusion, and the associated capillary hypertension, could lead to vascular damage [57], the observed changes could be a contributory factor to the impaired beta-cell function seen during these conditions. Furthermore, these findings highlight the importance of evaluating possible changes in the blood perfusion of transplanted islets.

\section{Engraftment of transplanted islets}

The engraftment, that is the adaptation of the transplanted cells to the implantation organ, is crucial for the ultimate function of the implanted islets. This is a complex process, encompassing among other things revascularization, reinnervation, ingrowth and/or expansion of stromal connective tissue cells and reorganization of the endocrine cells (Table 1). Furthermore, the inherent capacity of different implantation organs to stimulate e.g. angiogenesis, venous drainage and reinnervation should also be considered. This process has so far been partly addressed in several studies but the knowledge gained is far from complete. Increased information on this process will be a cornerstone for the development of techniques to diminish loss of endocrine cells after transplantation. In the discussion below, unless otherwise stated, we refer to cultured rodent islets implanted as an aggregate under the renal capsule of syngeneic recipients. Another issue which is important is species differences, not only in islet function [58], but also in vascular architecture and blood-flow regulation. As far as we have been able to ascertain there are no obvious differences with regard to angiogenesis and blood flow in human islets implanted into athymic nude mice when compared with other species. More subtle differences cannot of course be excluded.

Of particular importance for engraftment is the fact that islets are implanted either as single entities, or as aggregates of islets without, or with only minor amounts of associated exocrine tissue. Experimental studies where the islets are implanted into a skinfold chamber [59] or into the cheek pouch of hamsters [60, 
61, 62] are examples of the former, whereas aggregates of islets (usually 200-300) implanted under the renal capsule, or into the spleen $[63,64]$ are examples of the latter. Islet implantation intraportally into the liver, which is used in clinical islet transplantation, is done by means of an injection directly into the portal vein of aggregates of islets, which then presumably spread into portal tributaries within the liver parenchyma. This means that they can be found within the portal vasculature individually or as aggregates of a few islets. It should be noted in this context that, whereas in humans an even distribution is easy to achieve, the small size of the portal vein in rodents makes the placement of the portal catheter tip crucially important for the intra-hepatic distribution of the administered islets.

\section{Vasculature of transplanted islets}

Time schedule for revascularization. Unlike whole organ transplantations where a direct vascular anastomosis is established and blood flow is immediately restored, islets are implanted without any direct connection to the host vasculature. This issue has been addressed by several groups, and there is general agreement that intra-graft blood vessels can be seen within 3-5 days after transplantation and that there is a reestablishment of blood flow within 7-14 days [59, 65, $66,67,68,69,70]$. The required time seems to be independent of whether the islets are implanted singly, or in aggregates, or the implantation organ chosen. There are, however, few studies addressing the functional competence of these newly formed blood vessels. Studies in other systems suggest that newly formed blood vessels consist almost exclusively of endothelial cells. This means that they have not yet established a normal capillary structure, and thereby have a markedly increased wall permeability (see below). Some experiments suggest that a complete maturation, especially from a functional point of view, is not achieved until several months have passed, at least when aggregates of islets are implanted [63, 71].

Origin of graft blood vessels. The origin of the newly formed blood vessels within islet grafts has not been completely clarified. It has been suggested that culture of isolated islets induces the disappearance of endothelial cells, as well as macrophages, dendritic cells and nerve cells, since the in vitro conditions are not optimal for these cell types $[6,72]$. However, the lack of detectable endothelial cells after culture might not necessarily be due to an elimination of these cells, but can instead be caused by an endothelial dedifferentiation [73]. If this is the case, it could be that these cells once again assume their original phenotype and participate in the formation of new blood vessels after implantation. It is likely, however, that most, if not all, of the newly formed blood vessels originate from recipient blood vessels [74]. This is in analogy to what is seen with vascular smooth muscle tissue after experimental aortic implantations [75], and mesenchymal cells in kidney grafts [76]. However, recent studies suggest there could be a mixture of endothelial cells of both donor and recipient origin [77].

Because the implantation organ is likely to provide the newly formed blood vessels, it is important to clarify to what extent the angiogenic potential differs between different organs, as is the case for revascularization of tumours [78]. In a recent study we have found that there is indeed a difference in the degree of revascularization after the implantation of rodent islets to different organs [79]. Islets implanted into the kidney had more blood vessels than those within the spleen or liver. It should be noted that, in rodents, islets implanted intraportally into the liver survive for a shorter time span than islets at other sites [80], which could partially be explained by differences in revascularization.

Foetal islet-like cell clusters (ICC) are likely to contain immature precursor for endothelial cells, as well as angioblasts. Nevertheless, there is evidence for the occurrence of recipient endothelium within the grafted ICC. Indeed, foetal porcine ICC which develop endothelial cells during revascularization would be prone to hyperacute rejection when implanted into rodents. Because this does not occur [81] it is likely that most endothelium is derived from the host. In confirmation of this, transplantation of metanephroi from embryonic rats or mice has demonstrated that some parts of the vasculature are derived from the host [82, 83, 84]. It should be noted that it is not known when islets in foetuses become vascularized. Results from one study [85], suggest that it occurs during the last days of pregnancy in Mongolian gerbils. Presently, we have found that a fairly large number of blood vessels is present on day 20 in foetal rat pancreas (Fig. 2).

Mechanisms for graft revascularization: angiogenesis vs vasculogenesis. The most common form of angiogenesis, that is formation of blood vessels from preexisting microvasculature, is vascular sprouting [86, 87]. This has been found in transplanted foetal ICC $[88,89]$, and after implantation of adult islets $[59,66]$. It should be noted that vascular endothelial growth factor (VEGF) is expressed at different localities in foetal tissues [89], as well as in islets from adult donors [90], and could stimulate angiogenesis.

A more surprising finding was that there is intussusceptive capillary growth (Fig. 3) in foetal ICC grafts [88]. This means that new blood vessels are formed by ingrowth of tissue pillars into pre-existing blood vessels, which is an important contributor to the formation of new blood vessels [87]. It is, however, at present not known if this occurs also during revascularization of adult islets. 


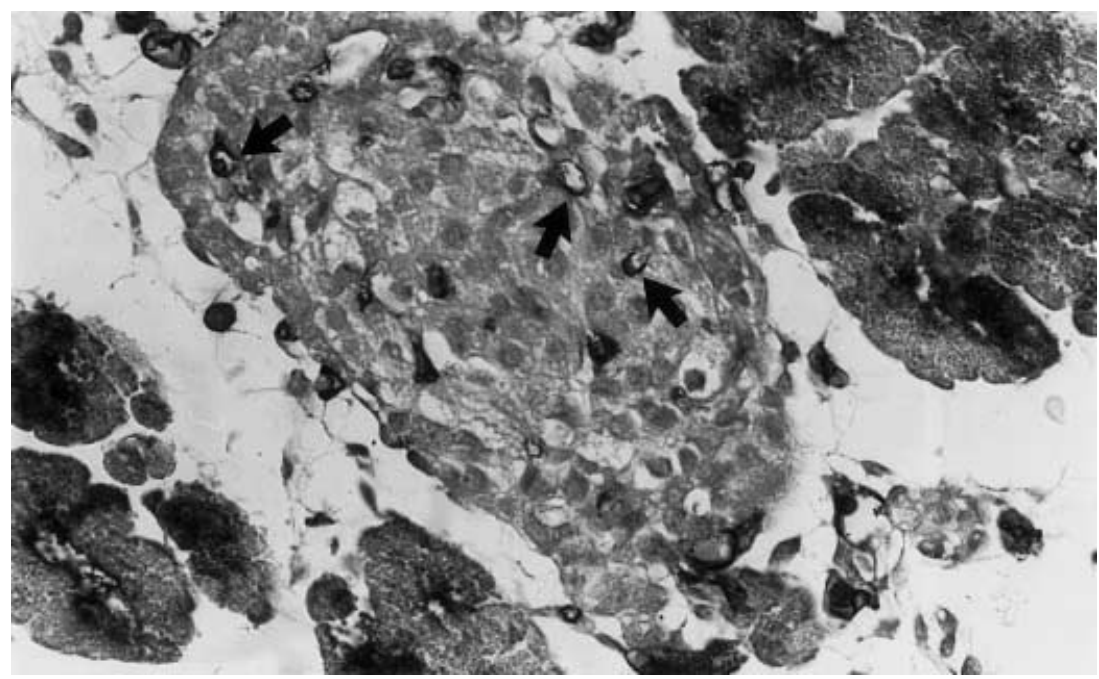

Fig. 2. Photomicrograph of an islet in the foetal rat pancreas day 20 of pregnancy. Endothelial cells (arrows) are stained with the lectin Bandairea simplicifolia-1. Magnification $\times 340$

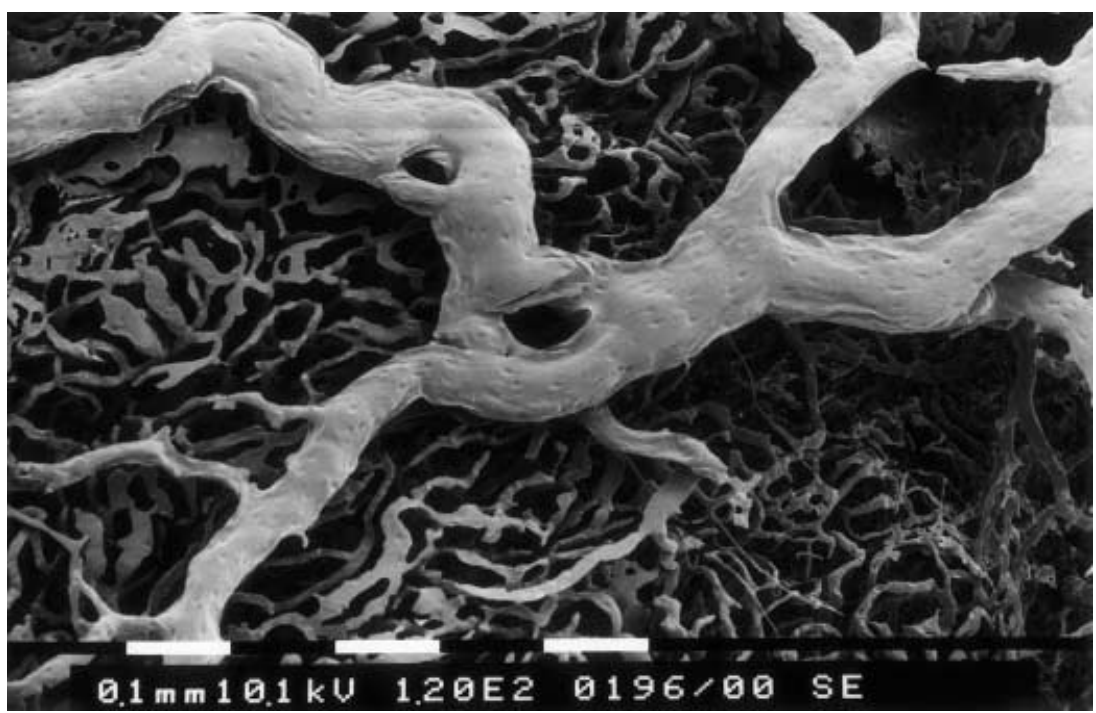

Fig. 3. Vascular corrosion cast prepared as given in [88] showing intussusceptive capillary growth. The holes within the cast represent tissue pillars. Scale bar is $100 \mu \mathrm{m}$

Normally the microvasculature is the origin of the newly formed blood vessels. Somewhat surprisingly, syngeneic islets transplanted intraportally into the liver in mice become revascularized almost exclusively from tributaries to the hepatic artery, and only to a small extent from the portal vein [67]. This is similar to tumours metastasing to the liver [91], suggesting that it is mainly arterial microvessels that are induced to form these particular angiogenic sprouts. It is not clear if the previously described instant blood mediated inflammatory reaction [92, 93], leading to an accumulation of trombocytes and subsequent release of e.g. plateled-derived growth factor, is involved in this process. It remains to be defined whether the main contribution of nutrients and oxygen to the graft is from the perfusing arterial blood vessels in direct contact with the endocrine cells of the islet core, or from the portal blood passing the periphery of the islets. This is, however, important because one of the arguments for implanting islets intraportally into the liver is that nutrients and other substances in the portal blood could directly affect islet function. In long-term intra-hepatic islet grafts there is often a disruption of the normal islet structure, with strands of endocrine cells sometimes entering the liver lobuli [94, 95], which probably improves blood supply.

There is a growing interest in the possible contribution of circulating stem cells or angioblasts or both to the revascularization of grafts. Such stem cells can differentiate into angioblasts and participate in angiogenesis [96]. They have even been used experimentally to improve, for example, the functions of ischaemic myocardium [97]. In a recent study on tumours, how- 
ever, there was no significant contribution of angioblasts to the revascularization process [98].

Morphology of graft capillaries. The blood vessels formed in the transplanted islets have morphological characteristics of those of endogenous islets, i.e. they consist of wide capillaries with a fenestrated endothelium $[65,95,99]$. Similar observations that ingrowing capillaries acquire a phenotype characteristic of the graft, e.g. the development of a blood-brain barrier after neural transplantations, have also been made in other cell transplantations [100]. It should be noted that this also seems to be independent of the implantation site $[65,72,101]$.

In an electron microscopical study on foetal porcine ICC and islets from adult mice, some of the ingrowing microvessels initially possessed a continuous endothelium but this was soon replaced by fenestrated cells [99]. This confirms that high islet hormone concentrations contribute to the formation of the fenestrae [102]. The recent observation in vitro that cultured islet endothelial cells possess fenestrae suggest that insulin is of major importance in this context [103].

Whether endothelial cells within islet grafts have similar functional capabilities as those of endogenous islets is not known. Previous studies have shown the presence of angiotensin-converting enzyme and endothelial nitric oxide synthase in endogenous islets [104, 105], as well as in transplanted islets (Mattsson, Carlsson and Jansson; unpublished observations). It is also not known to what extent the choice of implantation organ affects the phenotype of the intra-graft endothelium. In view of the discussion in the previous sections on the origin of transplant capillaries, this aspect of graft vasculature is worthy of further investigation.

Another issue of potential importance for the success of islet transplantation is the expression of different integrins on the endothelial cells, which could lead to leukocyte rolling and migration into islet tissues. Integrins are of crucial importance for the interaction with matrix proteins [106], which are important for the regulation of insulin release [107, 108]. At least some integrins are down-regulated after collagenase isolation and subsequent culture [109], but little is known of beta-cell integrin expression after transplantation of islets. Intercellular adhesion molecule-1 (ICAM-1) could be expressed on both human islet endocrine and endothelial cells and have been shown to be induced during culture [110, 111]. This induction of ICAM-1 seems to be at least partially mediated through cellular hypoxia and the increased expression of interferon- $\alpha$ (IFN- $\alpha)[111,112]$. Both in the immediate period after transplantation and later on, the transplanted islets also have a reduced tissue oxygen tension [64, 113]. However, to our knowledge no studies have investigated whether similar upregulation of IFN- $\alpha$ and ICAM-1 occurs in islet grafts. It is well known that interference with the functions of some adhesion molecules delays or prevents rejection after experimental islet transplantation, both in allogeneic $[114,115]$ and xenogeneic systems [116]. However, the extent to which these antibodies interfere with endothelial molecules, rather than those expressed on endocrine graft cells is not known. Expression of heat shock proteins after implantation is also likely to affect the expression of integrins on endothelial cells, thereby affecting recruitment of leukocytes into the graft [117].

Vascular channels and vascular mimicry. In the electron microscopical study of blood vessels in transplanted islets referred to above, we consistently noted the presence of erythrocyte-containing, non-endothelialized channels in the grafts [99]. In some instances we could even see beta-cell granules emptying into these spaces. Their frequency decreased with time but they persisted for at least up to 6 months after transplantation. This could represent a phenomenon similar to the so called vascular mimicry suggested to occur in some malignant tumours, where parenchyma and stromal cells form blood-filled channels within the tissue [118]. The functional importance of these structures awaits further studies. It can, however, be speculated that such structures could directly expose the surfaces of transplanted islets to trombocytes. Because the normal anticoagulant properties of the endothelium are absent, the trombocytes could become activated and thereby damage the grafts $[92,93]$.

Vascular density and architecture. Endogenous islets have in general been claimed to possess a dense vasculature but only few studies have quantitated this. A consistent finding has been that the endocrine pancreas has a higher vessel density than the exocrine parts of the gland [e.g. 119, 120, 121]. When single islets are implanted, angiogenesis leads to the formation of a glomerular-like vascular system similar to that of endogenous islets, and with a density higher than that seen in surrounding tissues [32]. A consensus from viewing histology slides of islets implanted as cellular aggregates, e.g. under the renal capsule, is that there is a vascular architecture similar to that of native islets [32]. This can be because the spaces the endothelial cells had been occupying remain within the islets and provide a path of least resistance for the ingrowing new blood vessels. Furthermore, it is possible that the basal lamina remains even after culture and thereby provides an appropriate matrix for the ingrowing endothelial cells.

Somewhat contrary to these notions, an intravital microscopy study showed a deterioration in the revascularization of aggregated islet transplants, even when clusters of only 50 islets were transplanted [122]. In line with this, we were able to show that vascular density in the endocrine tissue was in fact much lower after implantation, when compared with endogenous is- 
lets [79]. This was independent of whether the islets were implanted to the kidney, spleen or intraportally into the liver. However, it should be noted that islet grafts implanted into the spleen or under the renal capsule consist to a large extent (about 30\%) of connective tissue. Furthermore, a majority of the blood vessels in a graft is located to this stroma [79]. This means that, in contrast to endogenous islets, the implanted islets are surrounded by a tissue with higher vascular density. A tentative interpretation of these findings would be that islet grafts can induce angiogenesis, probably by expressing angiogenesis-stimulating factors such as vascular endothelial growth factor (VEGF) [123, 124, 125] in response to hypoxia, but that it does not lead to an adequate vascular ingrowth into the endocrine tissue. Instead there is a hypervascularity in the graft stroma for reasons which are not known. High local concentrations of insulin from the graft could affect capillary ingrowth, similar to what is seen with reinnervation of islet grafts [126], but this awaits experimental confirmation. Another confounding factor when analysing vascular densities in islet grafts is the possibility that the age of the islet donor could affect the angiogenic potential of the graft. It is known that donor age is inversely related to the replicatory rate within the grafts in experimental human islet transplantation [127]. There is also evidence to suggest that a similar correlation to graft blood flow exists [128]. However, if this is due to an impaired revascularization is not known.

It should be noted that the findings referred to above were made in transplanted adult islets. When transplanted foetal porcine ICC were studied by means of vascular corrosion casts, there was a vascular architecture similar to that of native islets [88]. However, a well developed stroma containing numerous blood vessels was also observed in these grafts.

A final comment on islet intra-graft capillary distribution is that the grafted islets are surrounded by blood both when implanted as aggregates into the spleen or kidney, or as single islets into the liver, in the former case from stromal capillaries, and in the second case by blood of the portal vein. Because islets also survive in vitro by receiving nutrients and oxygen through diffusion from the surrounding culture medium and in vivo after microencapsulation [129] it is logical that transplanted islets can partially compensate for the reduced number of microvessels by diffusion from surrounding blood or blood vessels or both.

When the direction of flow through transplanted single islets has been studied with in vivo microscopy, a flow from beta cells to non beta cells, similar to what is seen in endogenous islets (see above), has been found [130]. Of interest, reaggregated islet cells, forming so called pseudoislets, established this pattern with a core-to-mantle direction of the blood flow, and with a vascular density similar to that of other transplanted islets [131]. Whether or not a re-establishment of microvascular flow direction occurs in islets implanted as aggregates is at present not known. Some studies, nevertheless, suggest that this could be the case also during these circumstances [80], whereas another study suggests a marked change in blood perfusion with the non-beta-cell mantle being preferentially perfused [132].

Transplantation of islets also means that the insuloacinar portal system is interrupted and destroyed. Because the islet grafts are devoid of exocrine tissue, there would be no need for such a vascular system. It should be kept in mind that the implanted islets consist of large islets suitable for isolation by collagenase digestion [e.g. 6] lacking such a portal system. It has been debated to what extent human islets possess a portal system but recent findings make it likely that also these islets are drained by venulae after experimental implantation [25]. In recent experiments we have shown that both adult and foetal islets implanted under the renal capsule drain into venules, which then empty into larger veins covering the surface of the graft and finally into the inter-lobular veins of the kidney $[25,133]$. This means that the blood drainage is similar to that of native islets after transplantation as well.

A final issue of interest in this context is the possible formation of amyloid substance within the grafts. Islet-like amyloid polypeptide (IAPP) is formed in human islets and has been shown to accumulate between the endocrine cells and the capillaries after transplantation [134]. Because IAPP does not form fibrillar deposits in common laboratory animals, this means that the possible disturbance of such amyloid deposits on hormonal transport into the circulation is specific to implantation of human islets. Proteinaceous deposits around islets, although not distinctly fibrillar in nature, can be seen in the endogenous pancreas of rabbits after chronic duct ligation, but do not cause any obvious functional impairment in this model [135].

Factors influencing revascularization. Exocrine contamination after islet isolation could disturb angiogenesis and engraftment in general [101, 136]. Indeed, one of the reasons for culturing islets before transplantation has been to eliminate cells other than the endocrine, such as macrophages, dendritic cells, exocrine cells and endothelium. However, application of the Edmonton protocol [11] as well as some previous experimental studies [137] have shown that freshly isolated islets could be advantageous for engraftment. One possible explanation is that islets, and contaminating cells, contain endothelial cells which could facilitate angiogenesis. Recent findings [138] suggest that freshly isolated islets provide a higher partial pressure for oxygen within the grafts. In order to prove this further, studies addressing the long-term consequences of implantation of freshly isolated islets are clearly needed. 
A slower angiogenesis and overall engraftment seem to occur in transplanted smaller islets than large islets [139]. Dissociation of pancreatic islets, followed by reaggregation of the endocrine cells to pseudoislets, also delay the revascularization process [139]. The effects of cryopreservation, which at present is the only available method for long-term storage of islets [140], on revascularization has been studied to some extent. No effects on angiogenesis and vascular density after implantation of single islets were seen [141, 142]; neither could any negative influences be found on aggregated islets implanted under the kidney capsule [143]. It is likely that cryopreservation protocols optimised for the endocrine cells of the islets are less suitable for the survival of endothelial cells. However, it is obvious that this does not hamper the revascularization process.

Most studies of islet graft revascularization have been conducted in different syngeneic or immunocompromised animal models [9]. However, immune responses do not seem to affect the revascularization process as observed during the first week, although as the immune rejection progrediates, a reduction of the capillary network occurs as a consequence of the microvascular rejection [144, 145]. Cyclosporin in itself could affect angiogenesis $[66,146]$ and thereby islet graft vascular ingrowth. More recent analyses of the effects of different immunosuppressive drugs on the revascularization of free islet grafts have shown only slight changes in the vessel ingrowth, without any effect on microvascular perfusion as determined by intravital microscopy [32]. Thus, neither cyclosporin [147, 148], RS-61443 [149] nor prednisolone [150] caused any impairment in this process. Neither have any marked short-term effects of these immunosuppressive drugs on the blood perfusion of endogenous islets been observed [151]. It is at present not known whether the immunosuppressive drugs could adversely affect the blood perfusion of islet grafts. The influence of novel antirejection approaches, such as blockade of adhesion molecules or inhibition of oxygen radicals, on the revascularization of transplanted islets has not been studied much. A recent intravital microscopic study has shown that dietary supplementation with the antioxidant vitamin $\mathrm{E}$ could prevent islet xenograft rejection without affecting the angiogenesis in the grafts [145].

One issue of debate regarding revascularization of transplanted islets has been to what extent, if any, prevailing hyperglycaemia in the immediate period after transplantation affects angiogenesis and vascular ingrowth. Based on measurements of blood perfusion, it was initially suggested that hyperglycaemia could adversely affect revascularization [152, 153]. This has also indirectly been supported by studies on the gene expression of angiogenic factors and their receptors in islet grafts [90]. In this study, the authors could demonstrate a delay in the expression of both such factors and their corresponding receptors. In a careful study, investigators demonstrated, however, that revascularization in itself was not affected by persisting hyperglycaemia [154]. As mentioned above, however, the vascular density in grafts is lower. Moreover, the study by Menger was focussed on revascularization of single islets, not groups of islets. The effects of hyperglycaemia can therefore be interpreted to be mainly on the blood flow rather than on the angiogenic process, as discussed in further detail below.

\section{Function of vasculature of transplanted islets}

Blood perfusion. As mentioned above, endogenous pancreatic islets have a blood perfusion exceeding that of the exocrine parenchyma by a factor of 5-10. Initial studies with the microsphere technique on the blood perfusion of rodent islets implanted under the renal capsule have demonstrated a flow value similar to that of endogenous islets, i.e. $10-20 \mathrm{nl} / \mathrm{min}$ times islet. This is in line with the observations that single islets implanted subcutaneously have a high flow [32], even though this blood flow has never been measured. However, the measurements on transplanted islet aggregates were made on animals subjected to a partial pancreatectomy (to have access to autologous islets), which might have influenced the results. Furthermore, it cannot be excluded that so called preferential streaming of microspheres [155] could lead to an over-estimation of graft blood perfusion.

More recent studies from our laboratory, with laserDoppler flowmetry $[156,157]$ and a modified microsphere technique [133], have shown that the blood flow in transplanted adult islets is lower $(25-50 \%)$ than in the implantation organ (kidney, spleen, liver), and does not increase with time, at least up to 9 months after transplantation (Fig. 4). Similar findings have also been obtained in human islets implanted under the renal capsule of athymic nude mice [128]. These findings are more in line with the reduced vascular density in the islet grafts referred to above. Of interest is also the finding that there seems to be no difference in blood perfusion between cultured and freshly isolated islets after transplantation [138]. Persisting hyperglycaemia after implantation induces an increased islet blood flow, which is associated with a capillary hypertension [133] (see below). Because the revascularization is not affected by hyperglycemia [154], there could be a defect in the regulation of blood flow during hyperglycaemia. The possibility that an increased blood flow could be detrimental to the islets, due to increased shear stress on the endothelium [158], should be kept in mind, and is discussed further below.

The regulation of the blood perfusion in the newly formed intra-graft blood vessels is initially almost absent (cf. tumours; [159]). With time, however, at least 


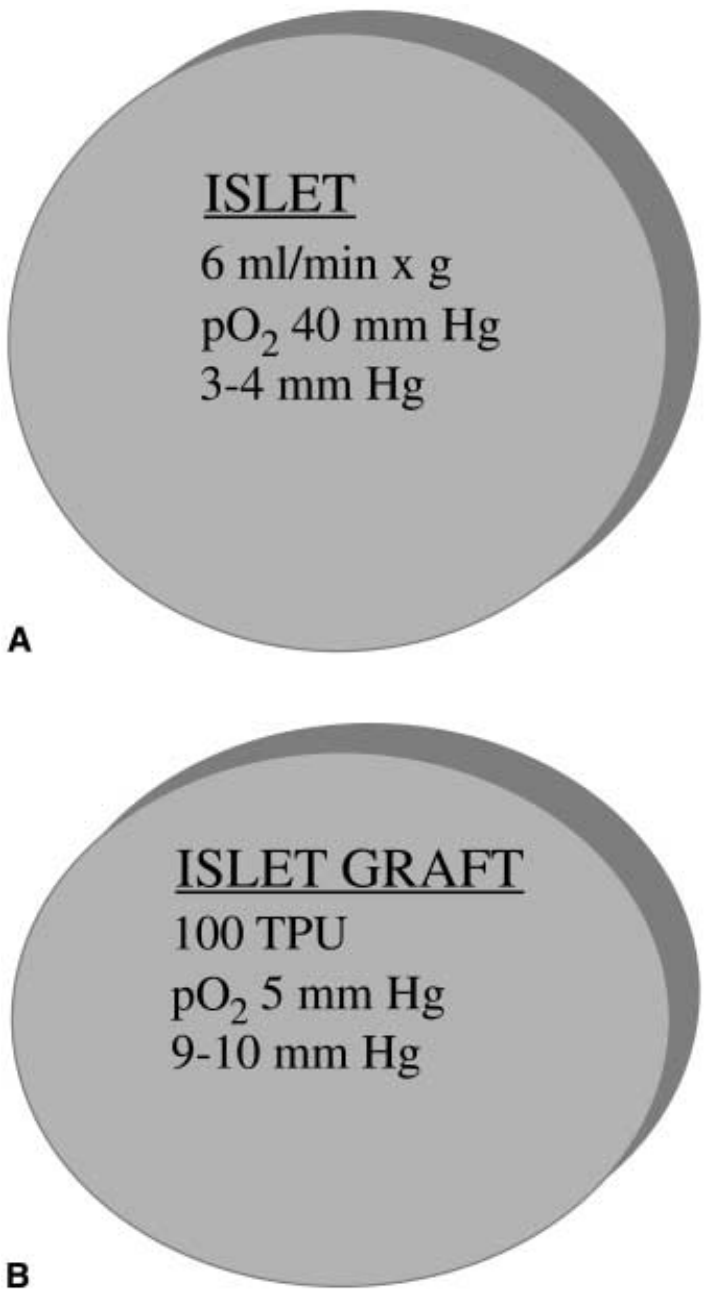

Fig. 4A, B. Schematic representation of blood flow values (upper value), partial pressure of oxygen $\left(\mathrm{pO}_{2}\right)$ and capillary blood pressures (lower value) in endogenous islets $(\mathbf{A})$, and in an islet graft implanted into kidney (B)

foetal islets achieve a blood perfusion which is sensitive to nitric oxide [40], similar to that seen in endogenous islets in both native and transplanted pancreata $[44,46]$. When examining adult islets in normoglycaemic and hyperglycaemic recipients 4 weeks after transplantation, we found an increased blood flow after administration of adenosine, whereas angiotensin II and the nitric oxide synthase (NOS) inhibitor $\mathrm{NG}^{\mathrm{G}}$-nitro-L-arginine induced a lower blood perfusion [156]. Prevailing hyperglycaemia after transplantation increased the sensitivity to angiotensin II and decreased that to NOS inhibition.

A consistent finding during reinnervation of islet grafts is that sympathetic nerve fibres are found adjacent to the blood vessels growing into the graft [39, 160]. The functional importance of these nerves for graft blood-flow regulation is not clear. However, a decreased sensitivity of insulin release to acetylcholine and an increased sensitivity to noradrenaline has been described in perifused islet grafts [161]. The latter argues for a denervation hypersensitivity [162].
To what extent this could explain the diminished blood flow in islet grafts has yet to be investigated.

Lymphatic capillaries and capillary blood pressure. Whether lymphatic capillaries, which are present in all commonly used implantation organs, develop in transplanted islets is of profound interest, because it will have major consequences for the understanding of blood-flow regulation in the graft. In endogenous islets there are no lymphatic capillaries [163], even though they could be present in their vicinity [164]. If lymphatic capillaries indeed exist in the transplant it means that the secreted hormones will not be exclusively removed by the blood circulation, but, to some extent, by lymphatic vessels draining into the systemic circulation as well. On the other hand, if lymphatic capillaries are absent, very high interstitial pressures are required within the central parts of the graft to maintain an adequate circulation, with associated large regional differences in the blood perfusion within the transplant (cf. tumor circulation) [159]. Preliminary findings have shown that lymphatic capillaries are indeed present in islets implanted under the renal capsule (Carlsson, Jansson and Källskog; unpublished observations), as also suggested by the low interstitial pressure values recorded in a previous study [133]. Interestingly, it has recently been shown that transgenic animals overexpressing VEGF-receptor $\mathrm{C}$ also express aberrant lymphatic vessels in close association with the islets [165].

In the newly formed capillaries of transplanted pancreatic islets there is a consistent increase in capillary blood pressure to levels similar to those of the implantation organ [133]. In endogenous islets the capillary pressure is only 3-4 mm Hg, which is markedly lower than in the implantation organs commonly used (Fig. 4). Moreover, no change with time after transplantation occurs $[53,133]$, which means that the islets are exposed to a chronic capillary hypertension after implantation. At present the effects of this are unknown, but in other organs, e.g. kidneys and retina, this increased shear stress is known to affect endothelial function, with possible effects also in the parenchymatous cells [57].

Oxygen pressure and metabolism in transplanted islets. One of the crucial functions of the newly developed vascular system in transplanted pancreatic islets is to deliver oxygen in sufficient quantities for the metabolic needs of the islet graft. It could be that oxygen delivery is far from optimal during the initial days after implantation. This has been suggested by measurements of oxygen tension in isolated Brockman bodies of fish [166] and in in vitro studies showing that islet function becomes impaired under prevailing low oxygen concentrations [167, 168]. Furthermore, endothelial cell function is also adversely affected by hypoxia [169], which could lead to a disturbance of graft blood flow. 
Measurements with Clark type oxygen microelectrodes with a guard cathode [157] (outer tip diameter of 5-6 $\mu \mathrm{m}$, and an inner tip diameter of $2 \mu \mathrm{m}$ ) have found that transplanted islets are hypoxic $(7-10 \mathrm{~mm}$ $\mathrm{Hg} ; 15 \%$ of normal partial pressure for oxygen), irrespective of implantation site (kidney, spleen, liver), without any improvement with time, for up to one year after transplantation [64, 157]. Similarly low tissue oxygen tensions have also been recorded in experimental human islet transplantation [128]. Interestingly, freshly isolated rodent islets have a markedly higher oxygen tension (3 times, i.e. $50 \%$ of that in endogenous islets; $20 \mathrm{vs} \mathrm{40-45} \mathrm{mm} \mathrm{Hg}$ ) [138].

The oxygen tension within grafted islets seems to be independent of the graft size, once engraftment has been established [157]. However, within the graft the gradient naturally depends on the size of the individual islets, because a large majority of the capillaries are located to the intra-graft stroma [79]. It is likely that the central parts of large individual islets could become hypoxic, and subsequently undergo necrosis or apoptosis or both, similar to the findings in cultured islets [6]. Furthermore, the appearance of so called blood lakes in aggregated islet grafts [9], that is an amorphous cellular debris mixed with blood cells, is likely to represent remnants of dying cells. A marked loss of islets in the period immediately after transplant, both due to necrosis and apoptosis, has also been found in several other studies [e.g. 13]. It is therefore likely that initial pressures of oxygen are less representative, due to the ongoing cell death. The hypoxia, anyhow, persists for several months after implantation, suggesting that there is a chronic hypoxia in aggregated islet grafts. The contribution of a decreased vascular density or changed blood flow regulation or both is not known.

Further support for the presence of a chronic hypoxia comes from our recent experiments with the microdialysis technique [170]. The principle for this technique is that the microdialysis probe should mimic a capillary blood vessel with respect to its permeability to substances $[171,172]$. Probes (outer diameter $0.5 \mathrm{~mm}$ ) with membranes with different cut off limits $(20,000$ or $100,000 \mathrm{kDa})$ are inserted with the aid of a cannula so that its entire membrane is within the graft. The probe is then continuously perfused with Ringer's solution at a low-flow rate $(0.3-2.0 \mu \mathrm{l} / \mathrm{min})$. Our preliminary experiments have shown that we can detect differences in glucose and insulin concentrations within grafts, which are likely to mirror the intra-transplant milieu. Of particular importance is our finding that the lactate-to-pyruvate ratio, i.e. a measure of the degree of anaerobic metabolism, is much higher in grafted islets of both normoglycaemic and hyperglycaemic recipients (by a factor of 5-7) than in cultured islets. This suggests that the observed low oxygen tension is associated also with a metabolic adaptation to the hypoxia.

\section{Interventions to improve graft vascular function}

The possibility of improving engraftment, especially with regard to revascularization, has been considered during the last decades. Several reports noticed some improvement in islet graft survival and revascularization by means of basic fibroblast growth factor (bFGF) [173, 174, 175], acidic FGF [173] and endothelial cell growth factor $[173,176]$ exposure of the graft. Furthermore, several studies have addressed the question to what extent other growth factors could affect growth, survival and differentiation of both adult and foetal transplanted islets [177]. Recently, it was shown that cultured and transplanted islets produce VEGF, which is an endothelialspecific growth factor contributing to most forms of angiogenesis [90, 123, 124]. An important field for future investigations is to evaluate the extent to which stimulation of angiogenesis could improve revascularization, and thereby, hopefully, also endocrine function.

Supplementation of the pancreas digestion medium with albumin has shown beneficial for islet function after transplantation [178]. This effect, however, does not seem to be due to improved revascularization, but other factors [179]. A possibility would be to coculture islets before transplantation with, or to implant them simultaneously with microvessels or angioblasts or both. The approach with implanted microvessels has proven successful with skin flaps [180] and with ex vivo expanded endothelial cells for amelioration of hind limb ischaemia in mice [181]. However, these suggestions remain conjectural.

\section{Conclusions}

Of crucial importance for the ultimate function of grafted pancreatic islets or whole pancreas is the engraftment as characterized by the revascularization, reinnervation and blood-flow regulation within the transplant. This is especially important in view of the shortage of islets suitable for transplantation, which means that damage of the endocrine cells after transplantation should be kept at a minimum. Evidence from experimental islet transplantation suggests that the vascular system of transplanted aggregates of islets is different from that of endogenous islets as manifested in a decrease in vascular density, blood flow and partial pressure of oxygen. Preliminary experiments also suggest that grafted islet aggregates have a marked degree of anaerobic metabolism. Such a metabolic derangement might well hamper a normal regulation of insulin secretion. It is important to ascertain whether impairments in vascular function are present after clinical islet transplantations to achieve optimal conditions for survival of transplanted beta cells in clinical trials. 
Sources. The review is based on the relevant literature published in the English language during the period 1985-2001, and in seminal prior contributions. The sources available to the authors were integrated with sources identified through PubMed searches for "islet transplantation and revascularization" and "islet transplantation and engraftment" and "islet transplantation and blood flow".

Acknowledgements Own work presented in this review has been made possible due to the technical skills of A. Nordin, B. Bodin and E. Törnelius. Financial support was received by grants from the Swedish Medical Research Council (72X-109), the NOVO Nordic Research Fund, the SwedishAmerican Diabetes Research Program funded by the Juvenile Diabetes Foundation International and the Wallenberg Foundation, the Swedish Diabetes Association, Svenska Barndiabetesfonden, Magnus Bergvalls Foundation, Turings Foundation, Lars Hiertas memorial Fund, Goljes Memorial Fund, the Swedish Society of Medicine and the Family Ernfors Fund.

\section{References}

1. Sowers JR (1996) Endocrinology of the vasculature. Humana Press, Totowa

2. Kolb H (1997) Benign versus destructive insulitis. Diabetes Metab Rev 13:139-146

3. Ludwig R, Kretschmer M, Caspar G et al. (1999) In vivo microscopy of murine islets of Langerhans: increased adhesion of transferred lymphocytes to islets depends on macrophage-derived cytokines in a model of organ-specific insulitis. Immunology 98:111-115

4. Uniyal S, Boeters L, Chakrabarti S, Singh B, Chan BM (1999) Leukocytes utilize both $\alpha 4$ and $\alpha 5$ integrins for intraislet infiltration in non-obese diabetic mice. J Autoimmun 12:167-176

5. Andersson A, Jansson L, Sandler S, Korsgren O, Sundler F (1994) Cell biology of the transplanted pancreatic islet: Impact of hyperglycaemia. In: Flatt PR, Lenzen S (eds) Insulin secretion and pancreatic B-cell research, Smith-Gordon, London, pp 605-611

6. Clayton HA, London NJM (1996) Survival and function of islets during culture. Cell Transplant 5:1-12

7. Carlsson P-O, Andersson A, Carlsson C et al. (2000) Engraftment and growth of transplanted pancreatic islets. Ups J Med Sci 105:107-123

8. Menger MD, Vollmar B (2000) Role of microcirculation in transplantation. Microcirculation 7:291-306

9. Lacy PE (1993) Status of islet cell transplantation. Diabetes Rev 1:76-92

10. International Islet Transplant Registry (2001) Newsletter 9 (available at http://www.med.uni-giessen.de/itrl)

11. Shapiro AM, Lakey JR, Ryan EA et al. (2000) Islet transplantation in seven patients with type 1 diabetes mellitus using a glucocorticoid-free immunosuppressive regimen. N Engl J Med 343:230-238

12. Ryan EA, Lakey JR, Rajotte RV et al. (2001) Clinical outcomes and insulin secretion after islet transplantation with the Edmonton protocol. Diabetes 50:710-719

13. Davalli AM, Scaglia L, Zangen DH, Hollister J, BonnerWeir S, Weir GC (1996) Vulnerability of islets in the immediate posttransplantation period: dynamic changes in structure and function. Diabetes 45:1161-1167
14. Bonner-Weir S (1993) The microvasculature of the pancreas, with special emphasis on that of the islets of Langerhans. In: DiMagno EP, Gardner JD, Lebenthal E, Reber HA, Scheele GA (eds) The pancreas: biology, pathobiology, and disease, second edition. Raven Press, New York, pp 759768

15. Brunicardi F, Stagner J, Bonner-Weir S et al. (1996) Microcirculation of the islets of Langerhans. Diabetes 45:385392

16. Thiel A (1954) Untersuchungen über das Gefäss-system des Pankreasläppchens bei verschiedenen Säugern mit besonderer Berücksichtigung der Kapillärknäuel der Langerhansschen Inseln. Z Zellforsch Mikrosh Anat 39:339372

17. Fujita T, Murakami T (1973) Microcirculation of monkey pancreas with special reference to the insulo-acinar portal system. A scanning electron microscope study of vascular casts. Arch Histol Jap 35:255-263

18. Henderson JR (1969) Why are the islets of Langerhans? Lancet ii:469-470

19. Henderson JR, Daniel PM, Fraser PA (1981) The pancreas as a single organ: the influence of the endocrine upon the exocrine part of the gland. Gut 2:158-167

20. Andreassi G (1966) Die Blutversorgung der Langerhansschen Inseln der menschlischen Bauchspeicheldrüse. Anat Anz 119:421-426

21. Murakami T, Fujita T, Taguchi T, Nonaka Y, Orita K (1992) The blood vascular bed of the human pancreas, with special reference to the insulo-acinar portal system. Scanning electron microscopy of corrosion casts. Arch Histol Cytol 55:381-395

22. Bunnag SC, Warner NE, Bunnag S (1964) Microvasculature of the pancreatic ducts. Bibl Anat 4:142-149

23. Lifson N, Lassa CV (1981) Note on the blood supply of the ducts of the rabbit pancreas. Microvasc Res 22:171-176

24. Ohtani O, Fujita T (1980) Microcirculation of the pancreas with special reference to periductular circulation. A scanning electron microscope study of vascular casts. Biomed Res 1:130-140

25. Jansson L, Tyrberg B, Carlsson P-O, Nordin A, Andersson A, Källskog Ö (2001) Microcirculation of human pancreatic islets transplanted under the renal capsule of nude mice. Transplantation 72:730-733

26. Sakamoto C, Goldfine ID, Roach E, Williams JA (1985) Localization of saturable CCK binding sites in rat pancreatic islets by light and electron microscope autoradiography. Diabetes 34:390-394

27. Samols E, Stagner JI (1996) Intra-islet cell-cell interactions and insulin secretion. Diabetes Rev 4:207-223

28. Bonner-Weir S, Orci L (1982) New perspectives on the microvasculature of the islets of Langerhans in the rat. Diabetes 31:883-889

29. Ohtani O, Ushiki T, Kanazawa H, Fujita T (1986) Microcirculation of the pancreas in the rat and rabbit with special reference to the insulo-acinar portal system and emissary vein of the islet. Arch Histol Jap 49:45-60

30. Liu Y-M, Guth PH, Kaneko K, Livingston EH, Brunicardi FC (1993) Dynamic in vivo observation of rat islet microcirculation. Pancreas 8:15-21

31. Jansson L (1994) The regulation of pancreatic islet blood flow. Diab Metab Rev 10:407-416

32. Menger MD, Yamauchi J-I, Vollmar B (2001) Revascularization and microcirculation of freely grafted islets of Langerhans. World J Surg 25:509-515

33. Lifson N, Kramlinger KG, Mayrand RR, Lender EJ (1980) Blood flow to the rabbit pancreas with special reference to the islets of Langerhans. Gastroenterology 79:466-473 
34. Meyer HH, Vetterlein F, Schmidt G, Hasselblatt A (1982) Measurement of blood flow in pancreatic islets: effect of isoproterenol and norepinephrine. Am J Physiol 242:E298E304

35. Jansson L, Hellerström C (1983) Stimulation by glucose of the blood flow to the pancreatic islets of the rat. Diabetologia 25:45-50

36. Jansson L, Hellerström C (1986) Glucose-induced changes in pancreatic islet blood flow mediated by central nervous system. Am J Physiol 251:E644-E647

37. Carlsson P-O, Iwase M, Jansson L (1999) Stimulation of intestinal glucoreceptors in rats increases pancreatic islet blood flow through vagal mechanisms. Am J Physiol 276:R233-R236

38. Carlsson P-O, Iwase M, Jansson L (2000) Intraportal glucose infusion and pancreatic islet blood flow in anesthetized rats. Am J Physiol 279:R1224-R1229

39. Korsgren O, Jansson L, Andersson A, Sundler F (1993) Reinnervation of transplanted pancreatic islets. A comparison among islets implanted into the kidney, spleen and liver. Transplantation 56:138-143

40. Korsgren O, Karlsten R, Sundler F, Jansson L (1996) Blood flow regulation in the transplanted fetal endocrine pancreas. Acquisition of a nitric oxide-dependent glucoseinduced increase in blood flow. Transplantation 61:772777

41. Persson-Sjögren S, Forsberg S, Täljedal I-B (2000) Peptides and other neuronal markers in transplanted pancreatic islets. Peptides 21:741-752

42. Jansson L, Korsgren O, Wahlberg J, Andersson A (1992) Pancreatic islet blood flow after syngeneic pancreaticoduodenal transplantation in rats. Differences between the blood perfusion of the native and transplanted gland. Transplantation 53:517-521

43. Jansson L, Carlsson P-O (1998) Adenosine and pancreatic islet blood flow in rats. Eur J Endocrinol 138 [Suppl 1]:10

44. Svensson AM, Östenson C-G, Sandler S, Efendic S, Jansson L (1994) Inhibition of nitric oxide synthase by $\mathrm{NG}_{-}$ nitro-L-arginine causes a preferential decrease in pancreatic islet blood flow in normal rats and spontaneously diabetic GK rats. Endocrinology 135:849-853

45. Moldovan S, Livingston E, Zhang RS, Kleinman R, Guth P, Brunicardi FC (1996) Glucose-induced islet hyperemia is mediated by nitric oxide. Am J Surg 171:16-20

46. Svensson AM, Sandler S, Jansson L (1995) The blood flow in pancreatico-duodenal grafts in rats: inhibition of nitric oxide synthase preferentially decreases islet blood flow. Eur J Pharmacol 275:99-103

47. Carlsson P-O, Berne C, Jansson L (1998) Angiotensin II and the endocrine pancreas: effects on islet blood flow and insulin secretion in rats. Diabetologia 41:127-133

48. Carlsson P-O (2001) The renin-angiotensin system and the endocrine pancreas. The JOP 2:26-31

49. Beppu H, Maruta K, Kürner T, Kolb H (1987) Diabetogenic action of streptozotocin: essential role of membrane permeability. Acta Endocrinol 114:90-95

50. Svensson AM, Abdel-Halim SM, Efendic S, Jansson L, Östenson C-G (1994) Pancreatic and islet blood flow in $\mathrm{F}_{1}$-hybrids of the non-insulin-dependent diabetic GKWistar rat. Eur J Endocrinol 130:612-616

51. Atef N, Portha B, Pénicaud L (1994) Changes in islet blood flow in rats with NIDDM. Diabetologia 37:677-680

52. Svensson AM, Jansson L, Hellerström C (1996) Dietinduced obesity and pancreatic islet blood flow in the rat: a preferential increase in islet blood perfusion persists after withdrawal of the diet and normalization of body weight. J Endocrinol 151:507-511
53. Carlsson P-O, Jansson L, Östenson C-G, Källskog Ö (1997) Islet capillary blood pressure increase mediated by hyperglycemia in NIDDM GK rats. Diabetes 46:947-952

54. Mizuno A, Noma Y, Kuwajima M, Murakami T, Zhu M, Shima K (1999) Changes in islet capillary angioarchitecture coincide with impairs B-cell function but not with insulin resistance in male Otsuka-Long-Evans-Tokushima fatty rats: dimorphism of the diabetic phenotype at an advanced age. Metabolism 48:477-483

55. Carlsson P-O, Sandler S, Jansson L (1998) Pancreatic islet blood perfusion in the nonobese diabetic mouse: diabetesprone female mice exhibit a higher blood flow compared with male mice in the prediabetic phase. Endocrinology 139:3534-3541

56. Suschek CV, Bonmann E, Kolb-Bachofen V (1999) A regulatory defect of constitutive NO-synthase in islet endothelial cells correlates with probability of disease manifestation in BBdp rats. Diabetologia 42:457-464

57. Zatz R, Brenner BM (1986) Pathogenesis of diabetic microangiopathy. Am J Med 80:443-453

58. Feldman JM (1979) Species variation in the islets of Langerhans. Diabetologia 16:1-4

59. Menger MD, Jäger S, Walter P, Feifel G, Hammersen F, Messmer K (1989) Angiogenesis and hemodynamics of microvasculature of transplanted islets of Langerhans. Diabetes 38 [Suppl 1]:199-202

60. Hansell P, Maione TE, Borgström P (1995) Selective binding of platelet factor 4 to regions of active angiogenesis in vivo. Am J Physiol 269:H829-H836

61. Borgström P, Torres Filho IP, Vajkoszy P, Strandgården K, Polacek J, Hartley-Asp B (1994) The quinoline-3-carboxamide Linomide inhibits angiogenesis in vivo. Cancer Chemother Pharmacol 34:280-286

62. Hansell P, Olofsson M, Maione TE, Arfors KE, Borgström P (1995) Differences in binding of platelet factor 4 to vascular endothelium in vivo and endothelial cells in vitro. Acta Physiol Scand 154:449-459

63. Rooth P (1988) Fluorescence microscopy of microcirculation in mouse pancreatic islets and renal cortex. [Medical Dissertation] Umeå University, Umea 226:1-102

64. Carlsson P-O, Palm F, Andersson A, Liss P (2000) Chronically decreased oxygen tension in rat pancreatic islets transplanted under the kidney capsule. Transplantation 69:761-766

65. Hart TK, Pino RM (1986) Pseudoislet vascularization: induction of diaphragm-fenestrated endothelia from the hepatic sinusoids. Lab Invest 54:304-313

66. Rooth P, Dawidson I, Lafferty K et al. (1989) Prevention of detrimental effect of cyclosporin A on vascular ingrowth of transplanted pancreatic islets with verapamil. Diabetes 38 [Suppl 1]:202-205

67. Andersson A, Korsgren O, Jansson L (1989) Intraportally transplanted pancreatic islets revascularized from hepatic arterial system. Diabetes 38 [Suppl 1]:192-195

68. Sandberg J-O, Margulis B, Jansson L, Karlsten R, Korsgren O (1995) Transplantation of fetal porcine pancreas to diabetic or normoglycemic nude mice. Transplantation 59:1665-1669

69. Vajkoszy P, Menger MD, Simpson E, Messmer K (1995) Angiogenesis and vascularization of murine pancreatic islet isografts. Transplantation 60:123-127

70. Adeghate E (1998) Host-graft circulation and vascular morphology in pancreatic tissue transplants in rats. Anat Rec 251:448-459

71. Jansson L, Sandler S (1992) The blood perfusion of transplanted pancreatic islets. Evidence for a maturation of the blood-flow response to D-glucose with time after implantation. Transplantation 53:1368-1369 
72. Parr E, Bower K, Lafferty K (1980) Changes in cultured mouse thyroid gland and islets of Langerhans. Transplantation 30:135-141

73. Bicknell R (1996) Endothelial cell culture. Cambridge University Press, Cambridge

74. Vajkoszy P, Olofsson AM, Lehr HA et al. (1995) Histogenesis and ultrastructure of pancreatic islet graft microvasculature. Evidence for graft revascularization by endothelial cells of host origin. Am J Pathol 146:13971405

75. Li J, Han X, Jiang J et al. (2001) Vascular smooth muscle cells of recipient origin mediate intimal expansion after aortic allotransplantation in mice. Am J Pathol 158:19431947

76. Grimm PC, Nickerson P, Jeffery J et al. (2001) Neointimal and tubulointerstitial infiltration by recipient mesenchymal cells in chronic renal-allograft rejection. $\mathrm{N}$ Engl J Med 345:93-97

77. Schneider K, Hammes H-P, Deutsch U et al. (2000) Endothelial cells from donor and host origin contribute to revascularization in islet transplantation. Diabetes 49 [Suppl 1]:A52 (Abstract)

78. Roberts WG, Delaat J, Nagane M, Huang S, Cavenee WK, Palade GE (1998) Host microvasculature influence on tumor vascular morphology and endothelial gene expression. Am J Pathol 153:1239-1248

79. Mattsson G, Jansson L, Carlsson P-O (2002) Vascular density in mouse pancreatic islets after transplantation. Cell Transplant. Diabetes 751:1362-1366

80. Hiller WFA, Klempnauer J, Lûck R, Steiniger B (1991) Progressive deterioration of endocrine function after intraportal but not kidney subcapsular rat islet transplantation. Diabetes 40:134-140

81. Korsgren O, Jansson L (1994) Discordant cellular xenografts revascularized in intermediate athymic hosts fail to induce a hyperacute rejection when transplanted to immunocompetent rats. Transplantation 57:1408-1411

82. Sariola H, Ekblom P, Lehtonen E, Saxen L (1983) Differentiation and vascularization of the metanephric kidney grafted on the chorioallantoic membrane. Dev Biol 96: 427-435

83. Hyink DP, Tucker DC, St John PL et al. (1996) Endogenous origin of glomerular endothelial and mesangial cells in grafts of embryonic kidneys. Am $\mathrm{J}$ Physiol 270:F886-F889

84. Rogers SA, Hammerman MR (2001) Transplantation of rat metanephroi into mice. Am J Physiol 280:R1865R1869

85. Chilvers ER, Thomas NW (1983) The blood supply of the islets of Langerhans in the Mongolian gerbil. J Anat $136: 339-347$

86. Kurz H (2000) Physiology of angiogenesis. J Neurooncol 50:17-35

87. Patan S (2000) Vasculogenesis and angiogenesis as mechanisms of vascular network formation, growth and remodeling. J Neurooncol 50:1-15

88. Korsgren O, Christofferson R, Jansson L (1999) Angiogenesis and angioarchitecture of transplanted fetal porcine islet-like cell clusters. Transplantation 68:1761-1766

89. Weinstein BM (1999) What guides early embryonic blood vessel formation? Dev Dyn 215:2-11

90. Vasir B, Jonas J-C, Steil GM et al. (2001) Gene expression of VEGF and its receptor Flk-1/KDR and Flt-1 in cultured and transplanted rat islets. Transplantation 71:924-935

91. Burgener FA (1980) Peripheral hepatic artery embolization in rabbits with VX2 carcinomas of the liver. Cancer 46:56-63
92. Bennet W, Sundberg B, Groth CG et al. (1999) Incompatibility between human blood and isolated islets of Langerhans: a finding with implications for clinical intraportal islet transplantation? Diabetes 48:1907-1914

93. Bennet W, Sundberg B, Lundgren T et al. (2000) Damage to porcine islets of Langerhans after exposure to human blood in vitro, or after intraportal transplantation to cynomolgus monkeys: protective effects of sCR1 and heparin. Transplantation 69:711-719

94. Griffith RC, Scharp DW, Hartman BK, Ballinger WF, Lacy PE (1977) A morphologic study of intrahepatic portal-vein islet isografts. Diabetes 26:201-212

95. Cassell L, Wohlrab F, Blech W, Hahn HJ (1990) Morphological findings in the liver of diabetic rats after intraportal administration of neonatal isologous pancreatic islets. Virchows Arch 59:65-75

96. Crisa L, Cirulli V, Smith KA, Ellisman MH, Torbett BE, Salomon DR (1999) Human cord blood progenitors sustain thymic T-cell development and a novel form of angiogenesis. Blood 94:3928-3940

97. Kocher AA, Schuster MD, Szabolcs MJ et al. (2001) Neovascularization of ischemic myocardium by human bone-marrow-derived angioblasts prevents cardiomyocyte apoptosis, reduced remodeling and improves cardiac function. Nat Med 7:430-436

98. Davidoff AM, Ng CY, Brown P et al. (2001) Bone marrow-derived cells contribute to tumor neovasculature and, when modified to express an angiogenesis inhibitor, can restrict tumor growth in mice. Clin Cancer Res 7:28702879

99. Lukinius A, Jansson L, Korsgren O (1995) Ultrastructural evidence for blood vessels devoid of an endothelial lining in transplanted pancreatic islets. Am J Pathol 146:429435

100. Akiyama H, Kondoh $\mathrm{T}$, Kokunai $\mathrm{T}$, Nagashima $\mathrm{T}$, Saito N, Tamaki N (2000) Blood-brain barrier formation of grafted human umbilical vein endothelial cells in athymic mouse brain. Brain Res 858:172-176

101. Gray DWR, Sutton R, McShane P, Peters M, Morris PJ (1988) Exocrine contamination impairs implantation of pancreatic islets transplanted beneath the kidney capsule. J Surg Res 45:432-442

102. Henderson JR, Moss MC (1985) A morphometric study of the endocrine and exocrine capillaries of the pancreas. Q J Exp Physiol 70:347-356

103. Lou J, Triponez F, Oberholzer J et al. (1999) Expression of alpha-1 proteinase inhibitor in human islet microvascular endothelial cells. Diabetes 48:1773-1778

104. Chappell MC, Milsted A, Diz DI, Brosnihan KB, Ferrarion CM (1991) Evidence for an intrinsic angiotensin system in the canine pancreas. J Hypertensi 9:751-759

105. Suschek C, Fehsel K, Kröncke K-D, Sommer A, KolbBachofen V (1994) Primary cultures of rat islet capillary endothelial cells. Am J Pathol 145:685-695

106. Longhurst CM, Jennings LK (1998) Integrin-mediated signal transduction. Cell Mol Life Sci 54:514-526

107. Kantengawa S, Baetens D, Sadoul K, Buck CA, Halban P, Rouiller D (1997) Identification and characterization of $\alpha 3 \beta 1$ integrin on primary and transformed rat islet cells. Exp Cell Res 237:394-402

108. Bosco D, Meda P, Halban PA, Rouiller DG (2000) Importance of cell-matrix interactions in rat islet $\beta$-cell secretion in vitro. Role of $\alpha-6 \beta-1$ integrin. Diabetes 49:233-243

109. Wang RN, Paraskevas S, Rosenberg L (1999) Characterization of integrin expression in islets isolated from hamster, canine, porcine, and human pancreas. J Histochem Cytochem 47:499-506 
110. Vives M, Soldevila G, Alcalde L, Lorenzo C, Somoza N, Pujol-Borrell R (1991) Adhesion molecules in human islet beta-cells. De novo induction of ICAM-1 but not LFA-3. Diabetes 40:1382-1390

111. Chakrabarti D, Huang X, Beck J et al. (1996) Control of islet intercellular adhesion molecule- 1 expression by interferon- $\alpha$ and hypoxia. Diabetes 45:1336-1343

112. Campbell IL, Cutri A, Wilkinson D, Boyd AW, Harrison LC (1989) Intercellular adhesion molecule 1 is induced on isolated endocrine islet cells by cytokines but not by reovirus infection. Proc Natl Acad Sci USA 86:4282-4286

113. Carlsson P-O, Liss P, Andersson A, Jansson L (1998) Measurements of oxygen tension in native and transplanted rat pancreatic islets. Diabetes 47:1027-1032

114. Arai K, Sunamura M, Wada Y et al. (1999) Preventing effect of anti-ICAM-1 and anti-LFA-1 monoclonal antibodies on murine islet allograft rejection. Int $\mathrm{J}$ Pancreatol 26:23-31

115. Katz SM, Bennett F, Stecker K et al. (2000) ICAM-1 antisense oligodeoxynucleotide improves islet allograft survival and function. Cell Transplant 9:817828

116. Grochowiecki T, Gotoh M, Dono K et al. (2000) Induction of unresponsiveness to islet xenograft by MMC treatment of graft and blockage of LFA-1/ICAM-1 pathway. Transplantation 69:1567-1571

117. Pockley AG (2001) Heat shock proteins, anti-heat shock protein reactivity and allograft rejection. Transplantation 71:1503-1507

118. McDonald DM, Munn L, Jain RK (2000) Vasculogenic mimicry: how convincing, how novel, and how significant? Am J Pathol 156:383-388

119. Vetterlein F, Pethö A, Schmidt G (1987) Morphometric investigation of the microvascular system of pancreatic exocrine and endocrine tissue in the rat. Microvasc Res 34:231-238

120. Svensson AM, Jansson L, Hellerström C (1988) The volume and area of the capillaries in the endocrine and pancreas of the rat. Histochemistry 90:43-46

121. Bennis-Taleb N, Remacle C, Hoet JJ, Reusens B (1999) A low-protein isocaloric diet during gestation affects brain development and alters permanently cerebral cortex blood vessels in rat offspring. J Nutr 129:16131619

122. Heuser M, Wolf B, Vollmar B, Menger MD (1997) Die Transplantation Langerhans'scher Inseln als "OrganCluster" beeinträchtigt die Vaskularisierung in vivo und führt zu signifikantem Transplantatverlust. Langenbecks Arch Chir 97:229

123. Gorden DL, Mandriota SJ, Montesano R, Orci L, Pepper MS (1997) Vascular endothelial growth factor is increased in devascularized rat islets of Langerhans in vitro. Transplantation 63:436-443

124. Vasir B, Aiello LP, Yoon K-H, Quickel RR, BonnerWeir S, Weir GC (1998) Hypoxia induces vascular endothelial growth factor gene and protein expression in cultured rat islet cells. Diabetes 47:1894-1903

125. Watanabe H, Sumi S, Urushihata T et al. (2000) Immunohistochemical studies on vascular endothelial growth factor and platelet endothelial cell adhesion molecule-1/CD-31 in islet transplantation. Pancreas 21:165173

126. Myrsén U, Keymeulen B, Pipeleers DG, Sundler F (1996) Beta cells are important for islet innervation: evidence from purified rat islet-cell grafts. Diabetologia 39:54-59
127. Tyrberg B, Eizirik DL, Hellerström C, Pipeleers DG, Andersson A (1996) Human pancreatic $\beta$-cell DNA-synthesis in islet grafts decreases with increasing organ donor age but increases in response to glucose stimulation in vitro. Endocrinology 137:5694-5699

128. Carlsson P-O, Mattsson G, Liss P, Jansson L, Palm F (2000) Tissue oxygen tension and blood perfusion in transplanted human pancreatic islets. Diabetologia 43 [Suppl 1]:A29 (Abstract)

129. van Schilfgaarde R, de Vos P (1999) Factors influencing the properties and performance of microcapsules for immunoprotection of pancreatic islets. J Mol Med 77:199205

130. Menger MD, Vajkoszy P, Beger C, Messmer K (1994) Orientation of microvascular blood flow in pancreatic islet isografts. J Clin Invest 93:2280-2286

131. Beger C, Cirulli V, Vajkoszy P, Halban PA, Menger MD (1998) Vascularization of purified pancreatic islet-like cell aggregates (pseudoislets) after syngeneic transplantation. Diabetes 47:559-565

132. Stagner JI, Samols E (1994) Altered microcirculation and secretion in transplanted islets. Transplant Proc 26:11001102

133. Carlsson P-O, Jansson L, Andersson A, Källskog Ö (1998) Capillary blood pressure in syngeneic rat islets transplanted under the renal capsule is similar to that of the implantation organ. Diabetes 47:1586-1593

134. Westermark P, Eizirik DL, Pipeleers DG, Hellerström C, Andersson A (1995) Rapid deposition of amyloid in human islets transplanted into nude mice. Diabetologia 38:543-549

135. Lauer E, Stolte M, Zirngibl H, Gebhardt CH, Schwille PO (1986) Ultrastructure of the islets of Langerhans after long-term occlusion of the pancreatic duct system. Z Gastroenterol 24:700-708

136. Heuser M, Wolf B, Vollmar B, Menger MD (2000) Exocrine contamination of isolated islets of Langerhans deteriorates the process of revascularization after free transplantation. Transplantation 69:756-761

137. Gores PF, Sutherland DER (1993) Pancreatic islet transplantation: is purification necessary? Am J Surg 166: 538-542

138. Olsson R, Palm F, Andersson A, Carlsson P-O (2001) Increased tissue oxygen tension in rat islet grafts composed of freshly isolated versus cultured islets. Ups J Med Sci 106 [Suppl 2]:A57 (Abstract)

139. Wolf B, Heuser M, Vollmar B, Menger MD (1998) Bedeutung der Grösse der Langerhans'schen Inseln für ihre erfolgreiche Vaskularisierung nach freier Transplantation. Langenbecks Arch Chir 98:153-156

140. Korbutt GS, Pipeleers DG (1994) Cold-preservation of pancreatic beta cells. Cell Transplant 3:291-297

141. Menger MD, Pattenier J, Wolf B, Jäger S, Feifel G, Messmer K (1992) Cryopreservation of islets of Langerhans does not affect angiogenesis and revascularization after free transplantation. Eur Surg Res 24:89-96

142. Mendola JF, Corominola H, Gonzaels-Clemente JM et al. (1996) Follow-up study of the revascularization process of cryopreserved islets of Langerhans. Cryobiology 33:530

143. Merchant FA, Diller KR, Aggarwal SJ, Bovik AC (1997) Angiogenesis in cultured and cryopreserved pancreatic islet grafts. Transplantation 63:1652

144. Menger MD, Wolf B, Hobel R, Schorlemmer HU, Messmer K (1991) Microvascular phenomena during pancreatic islet graft rejection. Langenbecks Arch Chir 376:214-221 
145. Vajkoczy P, Lehr HA, Hübner C, Arfors KE, Menger MD (1997) Prevention of pancreatic islet xenograft rejection by dietary vitamin E. Am J Pathol 150:1487-1495

146. Hernandez GL, Volpert OV, Iniguez MA et al. (2001) Selective inhibition of vascular endothelial growth factormediated angiogenesis by cyclosporin A: roles of the nuclear factor of activated $\mathrm{T}$ cells and cyclooxygenase 2 . J Exp Med 193:607-620

147. Mendola JF, Goity C, Esmatjes E, Saenz A, FernandezCruz L, Gomis R (1997) Cyclosporine does not inhibit the process of revascularization of pancreatic islet transplantation. Cell Transplant 6:69-76

148. Vajkoszy P, Vollmar B, Wolf B, Menger MD (1999) Effects of cyclosporine A on the process of vascularization of freely transplanted islets of Langerhans. J Mol Med 77:111

149. Beger C, Menger MD (1997) RS-61443 prevents microvascular rejection of pancreatic islet xenografts. Transplantation 63:577-582

150. Menger MD, Wolf $B$, Jäger S, Walter $P$, Messmer $K$ (1990) The influence of prednisolone on revascularization of pancreatic islet grafts. Transplant Proc 22:20422043

151. Sandberg J-O, Groth C-G, Andersson A, Jansson L (1994) Acute effects of different immunosuppressive drugs on pancreatic, islet, renal, and arterial hepatic blood flow in anesthetized rats. Transpl Int 7:319-323

152. Sandler S, Jansson L (1987) Blood flow measurements in autotransplanted pancreatic islets of the rat. J Clin Invest 80:17-21

153. Jansson L, Sandler S (1990) Altered blood flow regulation in autotransplanted pancreatic islets of rats. Am J Physiol 259:E52-E56

154. Menger MD, Vajkoszy P, Leiderer R, Jäger S, Messmer K (1992) Influence of experimental hyperglycemia on microvascular blood perfusion in pancreatic islet isografts. J Clin Invest 90:1361-1369

155. Mörkrid L, Ofstad J, Willasen Y (1976) Effect of steric restriction on the intracortical distribution of microspheres in the dog kidney. Circ Res 39:608-615

156. Olsson R, Jansson L, Andersson A, Carlsson P.-O (2000) Local blood flow regulation in transplanted rat pancreatic islets: influence of adenosine, angiotensin II, and nitric oxide inhibition. Transplantation 70:280-287

157. Carlsson P-O, Palm F, Andersson A, Liss P (2001) Markedly decreased oxygen tension in transplanted rat pancreatic islets irrespective of the implantation site. Diabetes 50:489-495

158. Herrmann J, Lerman A (2001) The endothelium: dysfunction and beyond. J Nucl Cardiol 8:197-206

159. Baish JW, Netti PA, Jain RK (1997) Transmural coupling of fluid flow in microcirculatory network and interstitium in tumors. Microvasc Res 53:128-141

160. Korsgren O, Andersson A, Jansson L, Sundler F (1992) Reinnervation of syngeneic mouse pancreatic islets transplanted into renal subcapsular space. Diabetes 41:130-135

161. Shi CL, Sehlin J, Täljedal I-B (1996) Effects of UK14.304, noradrenaline, and propranolol on insulin release from transplanted mouse islets. Eur J Endocrinol 135:724728

162. Pipeleers DG, Pipeleers-Marichal MA, Karl IE, Kipnis DM (1978) Secretory capability of islets transplanted intraportally in the diabetic rats. Diabetes 27:817-824

163. O'Morchoe CC (1997) Lymphatic system of the pancreas. Microsc Res Tech 37:456-477
164. Regoli M, Bertelli E, Orazioli D, Fonzi L, Bastianini A (2001) Pancreatic lymphatic system in rodents. Anat Rec 263:155-160

165. Mandriota SJ, Jussila L, Jeltsch M et al. (2001) Vascular endothelial growth factor-C-mediated lymphangiogenesis promotes tumour metastasis. EMBO J 20:672-682

166. Schrezenmeir J, Gero L, Solhdju M et al. (1994) Relation between secretory function and oxygen supply in isolated islet organs. Transplant Proc 26:809-813

167. Dionne KE, Colton CK, Yarmush ML (1993) Effect of hypoxia on insulin secretion by isolated rat and canine islets of Langerhans. Diabetes 42:12-21

168. Papas KK, Long RC Jr, Constantinidis I, Sambanis A (1996) Effects of oxygen on metabolic and secretory activities of $\beta$ TC3 cells. Biochim Biophys Acta 1291:163166

169. Ali MH, Schlidt SA, Hynes KL, Marcus BC, Gewertz BL (1998) Prolonged hypoxia alters endothelial barrier function. Surgery 124:491-497

170. Carlsson P-O, Kiuru A, Nordin A et al. (2001) Shift to non-oxidative glucose metabolism in transplanted rat pancreatic islets as evidenced by microdialysis measurements. Acta Chir Austriaca 33 [Suppl 174]:O3-06

171. Bolinder J, Ungerstedt U, Arner P (1992) Microdialysis measurement of the absolute glucose concentration in subcutaneous adipose tissue allowing glucose monitoring in diabetic patients. Diabetologia 35:1177-1181

172. Lafontan M, Arner P (1996) Application of in situ microdialysis to measure metabolic and vascular responses in adipose tissue. Trends Pharmacol Sci 17:309-313

173. Stagner JI, Samols E (1990) The induction of capillary bed development by endothelial cell growth factors before islet transplantation may prevent ischemia. Transplant Proc 2:824-828

174. Hayek A, Lopez AD, Beattie GM (1990) Angiogenic peptides in pancreatic islet transplantation to diabetic rats. Transplantation 50:931-933

175. Hayek A, Beattie GM, Lopez AD, Chen P (1991) The use of digital image processing to quantitate angiogenesis induced by basic fibroblast growth factor and transplanted pancreatic islets. Microvasc Res 41:203-209

176. Stagner JI, Samols E (1992) Induction of angiogenesis by growth factors: relevance to pancreatic islet transplantation. EXS 61:381-385

177. García-Ocaña A, Vasavada RC, Takane KK, Cebrian A, Lopez-Talavera JC, Stewart AF (2001) Using $\beta$-cell growth factors to enhance human pancreatic islet transplantation. J Clin Endocrinol Metab 86:984-988

178. Field J, Farney A, Sutherland DER (1996) Improved islet isolation from rat pancreas using $35 \%$ serum albumin in combination with dextran gradient separation. Transplantation 61:1554-1558

179. Vajkoczy P, Menger MD (1997) Improved islet isolation by $10 \%$ albumin does not influence graft angiogenesis and vascularization. Exp Clin Endocrinol Diabetes 105: $152-155$

180. Nakano M, Nakajima Y, Kudo S, Tsuchida Y, Nakamura H, Fukuda O (1998) Effect of autotransplantation of microvessel fragments on experimental random-pattern flaps in the rat, Eur Surg Res 30:149-160

181. Kalka C, Masuda H, Takahashi T et al. (2000) Transplantation of ex vivo expanded endothelial progenitor cells for therapeutic neovascularization. Proc Nat Acad Sci USA 97:3422-3427 